University of Nebraska - Lincoln

DigitalCommons@University of Nebraska - Lincoln

West Central Research and Extension Center, North Platte

Agricultural Research Division of IANR

2012

\title{
Effect of Amount and Timing of Subsurface Drip Irrigation on Corn Yield
}

Simon J. van Donk

University of Nebraska-Lincoln, simon.vandonk@unl.edu

James L. Petersen

University of Nebraska - Lincoln, jpetersen2@unl.edu

Don R. Davison

University of Nebraska - Lincoln, ddavison1@unl.edu

Follow this and additional works at: https://digitalcommons.unl.edu/westcentresext

van Donk, Simon J.; Petersen, James L.; and Davison, Don R., "Effect of Amount and Timing of Subsurface Drip Irrigation on Corn Yield" (2012). West Central Research and Extension Center, North Platte. 73.

https://digitalcommons.unl.edu/westcentresext/73

This Article is brought to you for free and open access by the Agricultural Research Division of IANR at DigitalCommons@University of Nebraska - Lincoln. It has been accepted for inclusion in West Central Research and Extension Center, North Platte by an authorized administrator of DigitalCommons@University of Nebraska - Lincoln. 
Published in Irrigation Science (2012); doi: 10.1007/s00271-012-0334-4

Copyright (C) 2012 Springer-Verlag. Used by permission.

Submitted September 6, 2011; accepted March 20, 2012; published online April 7, 2012.

A contribution of the University of Nebraska Agricultural Research Division, supported in part by funds provided through the Hatch Act.

\title{
Effect of Amount and Timing of Subsurface Drip Irrigation on Corn Yield
}

\author{
Simon J. van Donk, ${ }^{1}$ James L. Petersen, ${ }^{2}$ and Don R. Davison ${ }^{2}$ \\ 1. Department of Biological Systems Engineering, West-Central Research and Extension Center, \\ University of Nebraska-Lincoln, 402 West State Farm Road, North Platte, NE 69101, USA \\ 2. West-Central Research and Extension Center, University of Nebraska-Lincoln, \\ 402 West State Farm Road, North Platte, NE 69101, USA \\ Corresponding author - Simon J. van Donk, email svandonk2@unl.edu
}

\begin{abstract}
A field study was conducted at North Platte, Nebraska in 2007-2009, imposing eight irrigation treatments, ranging from dryland to fully irrigated. Four of the eight treatments allowed for various degrees of water stress only after tasseling and silking. In 2007, corn yield ranged from $8.9 \mathrm{Mg} \mathrm{ha}^{-1}$ with a season total of $41 \mathrm{~mm}$ of irrigation water to $11.5 \mathrm{Mg} \mathrm{ha}^{-1}$ for the fully irrigated treatment $(264 \mathrm{~mm}$ of irrigation water). The treatment with the greatest reduction in irrigation water after tasseling and silking $(158 \mathrm{~mm})$ had a mean yield of $10.9 \mathrm{Mg} \mathrm{ha}^{-1}$, only $0.6 \mathrm{Mg} \mathrm{ha}^{-1}$ less than the fully irrigated treatment. In 2009 , yields ranged from 12.6 to $13.5 \mathrm{Mg} \mathrm{ha}^{-1}$. There were no significant yield differences between the irrigation treatments for several possible reasons: more in-season precipitation and cooler weather required less irrigation water; much of the irrigation water was applied after the most water-stress sensitive stages of tasseling and silking; and lower atmospheric demand allowed for soil water contents well below 50\% management allowed depletion (MAD) not to cause any yield losses.
\end{abstract}

\section{Introduction}

In western Nebraska, as in many other parts of the USA, irrigation water is becoming more scarce. Groundwater levels have been falling (McGuire 2004; McGuire and Fischer 1999), and stream flow has been decreasing, leading to some conflicts between political entities. For example, it has been a challenge for Nebraska to supply the required amount of water to Kansas through the
Republican River. Irrigated agriculture is a major water user, and a reduction in use of irrigation water throughout the Republican Basin would be additional water that could help meet stream flow requirements in the Republican River. Also, by pumping less irrigation water, irrigators will be able to reduce pumping cost, and more water could be available for competing needs including those of wildlife, endangered species, and hydroelectricity plants.

Water shortages have led to irrigation allocations (government-imposed restrictions on irrigation) that are common in western Nebraska and other areas. These allocations are expected to become more restrictive and more widespread throughout the state. Corn, the most important crop in Nebraska, is affected by these developments more than other crops because of its high water requirements. Corn producers need to make tough choices: fully irrigate less land area; deficit-irrigate more land area; and/or grow crops, such as winter wheat, that require less water but are also less profitable.

Efficient irrigation systems may contribute to the goal of water conservation. Subsurface drip irrigation (SDI) has the potential to be a more efficient irrigation system compared to center pivots and furrow irrigation. Lamm et al. (1995) found that for a silt loam soil in northwest Kansas, careful management of SDI systems can reduce net irrigation needs by nearly $25 \%$, while still maintaining top yields of $12.5 \mathrm{Mg} \mathrm{ha}^{-1}$. This reduction in net irri- 
gation needs is primarily associated with the reduction of deep percolation losses, elimination of runoff from irrigation, and reduction in soil evaporation. Additionally, drier surface soils allow for increased infiltration of precipitation (Lamm et al. 2011).

Payero et al. (2008) conducted a study to evaluate the effect of irrigation applied with SDI on field corn yield, crop evapotranspiration (ET), water use efficiency, and dry matter production in the semiarid climate of westcentral Nebraska. Eight treatments were imposed with irrigation amounts ranging from 53 to $356 \mathrm{~mm}$ in 2005 and from 22 to $226 \mathrm{~mm}$ in 2006. Treatments resulted in seasonal crop ET of 580-663 $\mathrm{mm}$ in 2005 and 466$656 \mathrm{~mm}$ in 2006. Yields between treatments differed by as much as 22\% in 2005 and 52\% in 2006.

If applying less than full irrigation, timing of irrigation applications becomes especially critical. Payero et al. (2009) conducted a two-year study at North Platte, Nebraska, on the timing of SDI with a fixed seasonal amount, $150 \mathrm{~mm}$, of irrigation water in each irrigation treatment. The fixed amount was used to mimic an irrigation allocation of $150 \mathrm{~mm}$ per year. They found that timing of irrigation did matter: corn yields were highest when most of the $150 \mathrm{~mm}$ was applied in July and lowest when most was applied in September.

Howell et al. (1997) conducted a study on clay loam soil in northwest Texas to evaluate the effect of subsurface and surface drip application methods on performance of corn. Irrigation frequency and application method (surface or subsurface drip) did not affect corn yields; however, deficit irrigation did negatively affect yields. Lamm and Trooien (2001) found that daily SDI application of $2.5 \mathrm{~mm}$ of water doubled corn grain yields in the extremely dry years of 2000 and 2001 in northwest Kansas. Their results suggested an irrigation capacity of $4.3 \mathrm{~mm} /$ day might be adequate when planning new SDI systems in this region with deep silt loam soils.

Colaizzi et al. (2004) conducted a three-year study in northwest Texas to compare SDI, low-energy precision application (LEPA), and spray irrigation for grain sorghum on a slowly permeable clay loam soil. Each irrigation method was compared at five irrigation levels: 0 , $25,50,75$, and $100 \%$ of crop evapotranspiration, simulating rainfed conditions and varying well capacities found in the region. In all 3 years, SDI had greater yield and water use efficiency than the other two irrigation methods at the $50 \%$ irrigation level and especially at the $25 \%$ level.

However, the cost of an SDI system is high. Currently, SDI may not be competitive with a center pivot for irrigating a row crop such as corn on a quarter section $(800 \mathrm{~m}$ by $800 \mathrm{~m})$ of land, which is a typical irrigation scenario for the western US Great Plains region. Also, rodents are often a problem with SDI (Lamm and
Camp 2007). They chew on the underground drip tape, causing leaks that may be difficult to find and repair. There is no easy solution to this problem. Maintaining less crop residue on the field may help - providing a less attractive habitat for the rodents. However, this would counteract the water-conservation objective of having an SDI system; maintaining more residues has been shown to conserve water (Steiner 1989; Todd et al. 1991; van Donk et al. 2004, 2010; Klocke et al. 2009). Nonetheless, with water becoming more scarce, SDI may become a more attractive alternative, even for large-scale, relatively low-value, row-crop production.

Many of the studies to evaluate irrigation scheduling for SDI, reviewed by Camp (1998), were initiated to determine whether reduced evaporation and improved irrigation efficiency would have a measurable effect on the irrigation requirement or its timing. The results did not answer this question conclusively; reductions in irrigation amount were found in some cases, but not in others (Camp 1998).

Past research focus in west-central Nebraska has been mostly on the more common sprinkler and surface irrigation systems (Payero et al. 2005, 2006a, b; Schneekloth et al. 2006). Local information on the response of SDI-irrigated corn is limited and this response can vary significantly from 1 year to the next. The objective of this study was to determine the effect of the amount and timing of irrigation on corn (Zea mays L.) yield using SDI.

\section{Methods}

The study was conducted from 2007 through 2009 at the University of Nebraska-Lincoln, West-Central Research and Extension Center (WCREC) in North Platte, Nebraska $\left(41^{\circ} 10^{\prime} \mathrm{N}, 100^{\circ} 45^{\prime} \mathrm{W}, 861 \mathrm{~m}\right.$ elevation above sea level) on a Cozad silt loam (fine-silty, mixed, mesic Fluventic Haplustoll) with an average water content at field capacity of $0.29 \mathrm{~m}^{3} \mathrm{~m}^{-3}$ and at wilting point of $0.11 \mathrm{~m}^{3} \mathrm{~m}^{-3}$ (Klocke et al. 1999). The climate at North Platte is semi-arid, with an average annual precipitation of $508 \mathrm{~mm}$ and a reference evapotranspiration of $1,403 \mathrm{~mm}$. On average, approximately $80 \%$ of the annual precipitation occurs during the growing season, which extends from late-April to mid-October (USDA 1978).

The experiment was conducted on a set of plots planted to field corn at a seeding rate of 79,000 seeds per ha using a six-row John Deere 7100 Max-Emerge planter. Each plot was $38.1 \mathrm{~m}$ long and $9.1 \mathrm{~m}$ (12 rows of corn) wide. No-till practices were used in all 3 years. The study used a randomized complete block design and was replicated four times. There were eight treatments to impose different irrigation regimes (Table 1). The rationale for the A treatments was to allow no water stress during the critical period of tasseling and silking (Table 2) 
Table 1. Irrigation treatments

\begin{tabular}{|c|c|}
\hline ID & Description of irrigation treatment \\
\hline DL & Dryland or rainfed (no irrigation) \\
\hline 50 & $\begin{array}{l}50 \% \text { ET (meet } 50 \% \text { of evapotranspiration requirements) } \\
\text { throughout the growing season }\end{array}$ \\
\hline 75 & $75 \%$ ET throughout the growing season \\
\hline 100 & $100 \%$ ET throughout the growing season \\
\hline 125 & $125 \%$ ET throughout the growing season (2009 only) \\
\hline A1 & $\begin{array}{c}\text { Start with 50\% ET, 100\% ET during } 2 \text { weeks starting at } \\
\text { tasseling, then 50\% ET (not in 2009) }\end{array}$ \\
\hline A2 & $\begin{array}{c}\text { Start with 50\% ET, } 100 \% \text { ET during } 3 \text { weeks starting at } \\
\text { tasseling, then } 50 \% \text { ET }\end{array}$ \\
\hline A3 & $\begin{array}{l}\text { Start with } 50 \% \text { ET, } 100 \% \text { ET during } 4 \text { weeks starting at } \\
\text { tasseling, then } 50 \% \text { ET }\end{array}$ \\
\hline A4 & $\begin{array}{c}\text { Start with } 75 \% \text { ET, } 100 \% \text { ET during } 4 \text { weeks starting at } \\
\text { tasseling, then } 75 \% \text { ET }\end{array}$ \\
\hline
\end{tabular}

Table 2. Observed corn growth stages and planting and harvest dates

\begin{tabular}{|c|c|}
\hline \multicolumn{2}{|l|}{2007} \\
\hline $5 / 14$ & Plant corn \\
\hline $5 / 21$ & Emergence \\
\hline $7 / 15$ & Tasseling \\
\hline $7 / 31$ & Fully silked \\
\hline $8 / 6$ & Pollination complete, silks brown \\
\hline $8 / 23$ & Beginning dent \\
\hline $9 / 12$ & Past $3 / 4$ milk line, but no black layer yet \\
\hline $10 / 2$ & Physiological maturity (black layer) \\
\hline $11 / 7$ & Harvest \\
\hline \multicolumn{2}{|l|}{2008} \\
\hline $5 / 21$ & Plant corn \\
\hline $6 / 1$ & Emergence \\
\hline $7 / 29$ & Tasseling \\
\hline $8 / 6$ & Pollination starting \\
\hline $8 / 20$ & Milk stage (R3) \\
\hline $9 / 4$ & Beginning dent \\
\hline $9 / 24$ & No black layer yet, close to $1 / 2$ milk line \\
\hline $10 / 13$ & Physiological maturity (black layer) \\
\hline 11/19-20 & Harvest \\
\hline \multicolumn{2}{|l|}{2009} \\
\hline $5 / 7$ & Plant corn \\
\hline $5 / 20$ & Emergence \\
\hline $7 / 24$ & Tasseling \\
\hline $9 / 2$ & Beginning dent \\
\hline $9 / 28$ & $1 / 2$ Milk line \\
\hline $10 / 7$ & No black layer yet \\
\hline $10 / 10$ & Physiological maturity (black layer) \\
\hline $12 / 16-17$ & Harvest \\
\hline
\end{tabular}

and to allow various levels of water stress before and after this period. In real-world situations, one would not want to limit irrigation too much before this critical period if irrigation capacity is low; the crop may be able to handle deficit irrigation during the vegetative stage,

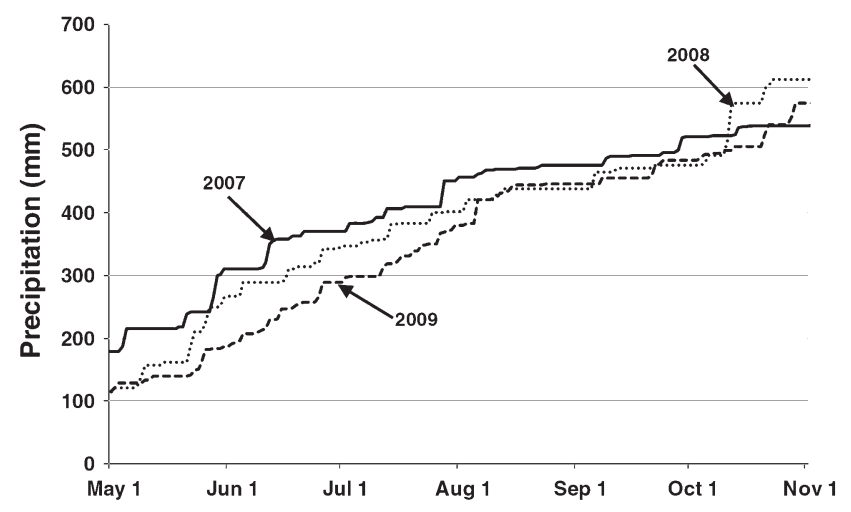

Figure 1. Cumulative precipitation at the experimental site, 2007-2009.

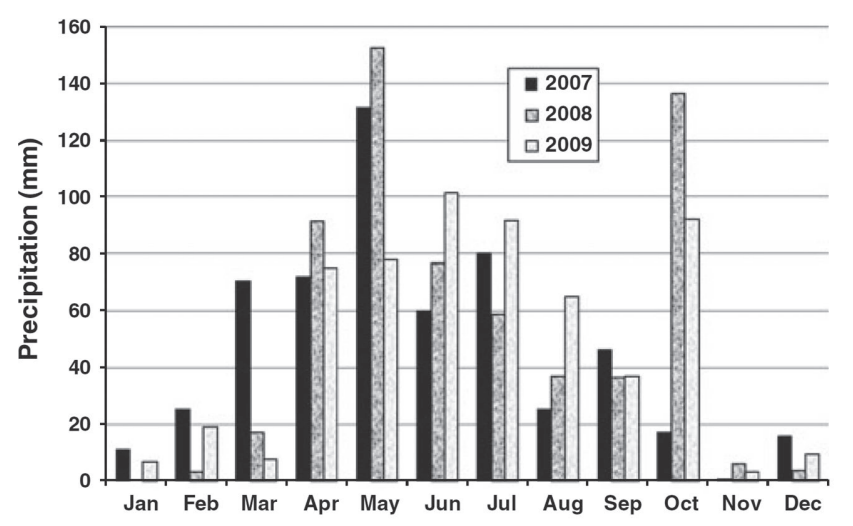

Figure 2. Monthly precipitation at the experimental site, 20072009.

but with a low irrigation capacity it may be difficult to catch up with irrigation in the critical period of tasseling and silking. In 2009, the A1 treatment was replaced by a $125 \%$ ET treatment.

During late spring and summer, precipitation was measured using several rain gauges located at the SDI plots. For the rest of the year, precipitation data from a High Plains Regional Climate Center (HPRCC, http:// www.hprcc.unl.edu/) weather station, located less than one $\mathrm{km}$ from the study site, were used. Measurement of precipitation in the form of snow at this HPRCC station did not appear very reliable. Therefore, for water equivalent data from snow, data was used from the WCREC dryland farm, which is located a few $\mathrm{km} \mathrm{NW}$ of the SDI plots. Thus, using these three data sources, a precipitation record was constructed for the entire 3 years of 2007-2009 (Figures 1 \& 2).

The SDI system was installed in 2005. The drip tape is spaced $1.52 \mathrm{~m}$ apart and located approximately $0.40 \mathrm{~m}$ below the soil surface, between two crop rows. Laterals are 12.5-mil thin-wall dripper lines (Dripnet PC 1613 F, Netafim USA, Fresno, CA) with an inside diameter of $1.6 \mathrm{~cm}$ and with pressure-compensating emitters spaced every $46 \mathrm{~cm}$. The nominal flow of the emitters is 
$0.98 \mathrm{~L} / \mathrm{h}$ at a pressure of $69 \mathrm{kPa}$. The SDI system applies $25.4 \mathrm{~mm}$ (1 inch) of water in approximately $17.5 \mathrm{~h}$.

Water for the SDI system is filtered using a 152-mm diameter screen filter with a 150-mesh screen (model $8060 F-M N$, Netafim USA, Fresno, CA). Irrigation to each treatment is controlled from a manifold that has eight branches. Each branch has a flow meter (25.4-mm model 36M251T), equipped with a pulse reed switch (model 36RD, Netafim USA, Fresno, CA). It also has a 19-mm electric/manual control valve (model S390-3-0, Dorot Control Valves Inc., Fresno, CA), a pressure regulator (Standard model, 0.22-1.26 L/s, $62.1 \mathrm{kPa})(\mathrm{Ne}-$ tafim USA, Fresno, CA), and an air and vacuum relief air vent with schrader valve (Guardian model, Netafim USA, Fresno, CA). Irrigations were controlled manually.

Irrigation treatments were applied three times a week unless rain made irrigation unnecessary. For example, there was no irrigation between $7 / 27$ and 8/10/2007 (Figure 3a) because of abundant rain (Figure 1) and low evapotranspiration values. In 2007 and 2009, the dryland treatment was not exclusively rainfed, because all plots, including the dryland plots, were fertigated at the beginning of the irrigation season (Figure $3 a, c)$.

A general rule for the irrigation of many crops is that the crop experiences no water stress as long as plant available water is greater than $50 \%$, halfway between field capacity and permanent wilting point, although this point of beginning water stress depends on a number of factors, including the type of crop, the crop growth stage, and the atmospheric evaporative demand. On a hot, dry day, when atmospheric demand is high, more stored soil moisture is needed than on a cool, humid day to avoid drought stress in a crop (Allen et al. 1998).

The first irrigation of the season was determined using a MAD of $50 \%$. Specifically, it was determined by not allowing the mean soil water content of the top $0.9 \mathrm{~m}$ (approximately representing the rooting depth at this time) to drop below $0.20 \mathrm{~m}^{3} \mathrm{~m}^{-3}$. For this silt loam soil, a soil water content of $0.20 \mathrm{~m}^{3} \mathrm{~m}^{-3}$ is halfway between soil water content at field capacity $\left(0.29 \mathrm{~m}^{3} \mathrm{~m}^{-3}\right)$ and that at wilting point $\left(0.11 \mathrm{~m}^{3} \mathrm{~m}^{-3}\right)$. In other words, half of the available water is depleted at a soil water content of $0.20 \mathrm{~m}^{3} \mathrm{~m}^{-3}$. In all three years, the spring was so wet, that it was not necessary to start irrigation much before tasseling. Thus, none of the treatments were subjected to water stress before tasseling.

Soil water content was measured approximately once a week during the growing season in each of the 32 plots at six depths $(0.15,0.46,0.76,1.07,1.37$, and $1.68 \mathrm{~m}$ ) using a neutron probe (CPN Hydroprobe) (Evett and Steiner 1995). There was one neutron tube per plot, always located within a row of corn. Corn rows were $0.76 \mathrm{~m}$ apart, which was half the drip tape spacing. Thus, one drip tape supplied water to two rows of corn.
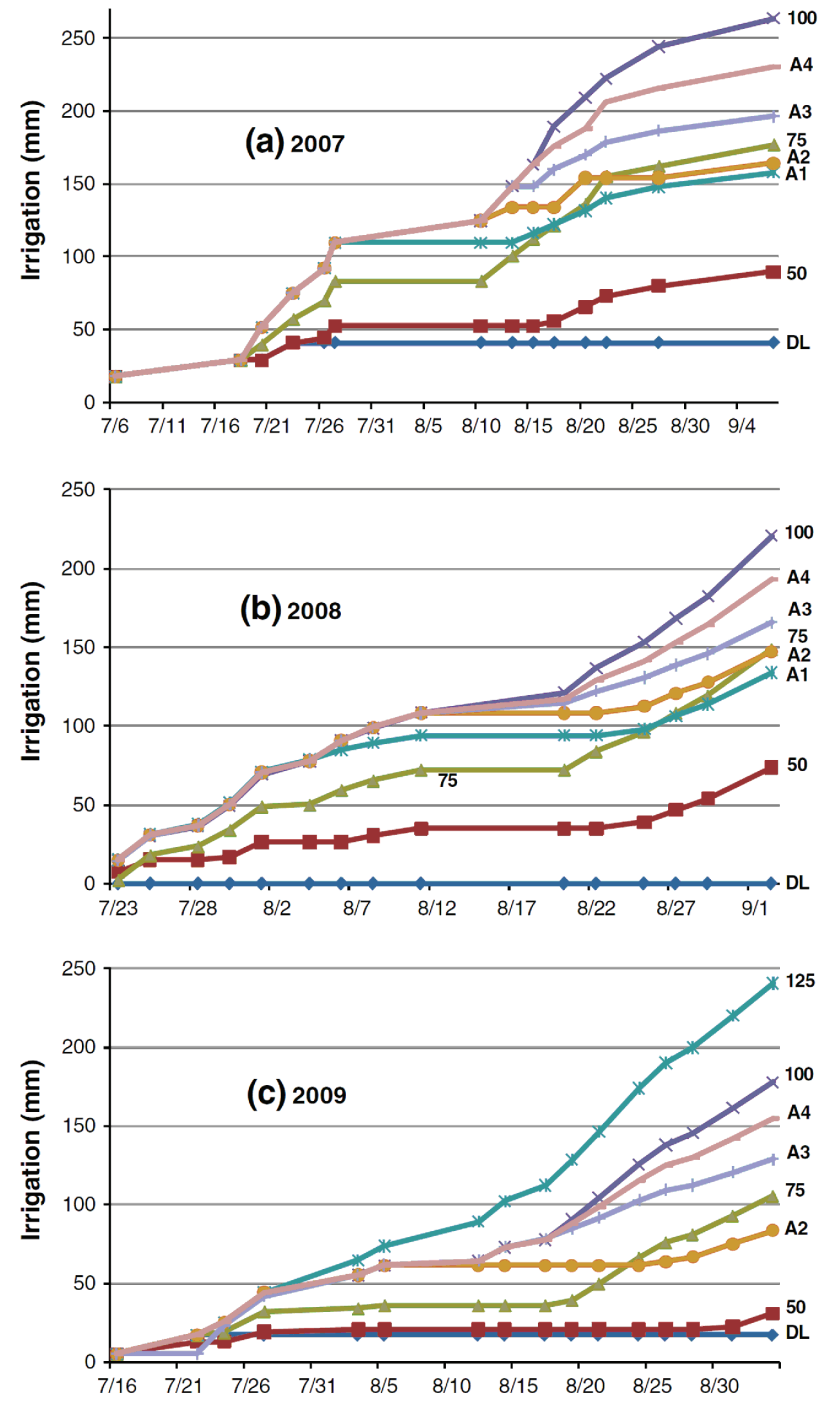

Figure 3. Cumulative irrigation for eight irrigation treatments. Descriptions of irrigation treatments are given in Table 1. Markers on the lines indicate irrigation dates.

Data from the HPRCC weather station were used to obtain daily corn crop evapotranspiration for fully watered conditions. The HPRCC algorithm uses the Penman equation to calculate reference ET. Corn crop ET is then calculated from reference ET and crop coefficients (Table 3). Actual observed emergence dates (Table 2) were used to determine the starting point of the crop coefficient curve.

During the growing season, it was verified that the actual observed crop growth stage did not differ significantly from the growth stage calculated by the HPRCC algorithm. This calculated ET was used to determine the amount of irrigation for the $100 \%$ ET treatment. Measured soil water content was used as a check to ensure that the $100 \%$ ET treatment was not falling below a MAD of $50 \%\left(0.20 \mathrm{~m}^{3} \mathrm{~m}^{-3}\right)$ on average in the top $0.9 \mathrm{~m}$ of soil or that that this treatment would be overirrigated; 
Table 3. Crop coefficients used in the calculation of corn crop evapotranspiration (ET)

\begin{tabular}{ll}
\hline Growth stage & Crop coefficient \\
\hline 2 Leaves & 0.10 \\
4 Leaves & 0.18 \\
6 Leaves & 0.35 \\
8 Leaves & 0.51 \\
10 Leaves & 0.69 \\
12 Leaves & 0.88 \\
14 Leaves & 1.01 \\
16 Leaves & 1.10 \\
Silks & 1.10 \\
Blister & 1.10 \\
Dough & 1.10 \\
Beginning dent & 1.10 \\
Full dent & 0.98 \\
Black layer & 0.60 \\
Full maturity & 0.10 \\
\hline
\end{tabular}

it was never necessary to correct for the irrigation scheduling based on ET. The irrigation amounts for all other treatments were based on the $100 \%$ ET treatment (Figure 3). Note that $50 \%$ ET or $75 \%$ ET does not mean that 50 or $75 \%$ of the irrigation amount delivered to the $100 \%$ treatment was applied. This would have been the case only if precipitation would have been zero. Both irrigation and precipitation contribute to meet the ET requirement. Thus, on a given day, it is possible to irrigate the $100 \%$ ET treatment but not some of the other treatments (Figure 3).

Total season ET, between emergence and maturity, was estimated for each irrigation treatment using measured water balance components (change in soil water content, precipitation, and irrigation, Table 4). Before the date of the first soil water measurement, ET was estimated using HPRCC data. In 2009, ET was also estimated using HPRCC data after the date of the last soil water measurement, because maturity occurred several weeks after this date. Irrigation in Table 4 is irrigation between the first and the last soil water measurements. For 2007 and 2008, this was equal to the total season irrigation. For 2009 , this is a little less than the total season irrigation, because there was one irrigation (applied on September 3) after the last soil water measurement (September 2).

A three-row plot combine was used to harvest the corn crop. The combine was equipped with a harvest data system (model HM-400, Juniper Systems Inc. Logan, Utah), which measured the mass and moisture content of the harvested grain. Corn that was harvested in two combine passes (six corn rows) in each plot was used in the yield calculation. Rows on the plot borders were excluded from the yield calculation. Yield was standardized (adjusted) to $15.5 \%$ grain moisture content. Statistical analysis of yield was conducted with SAS sta- tistical software (SAS Institute, Inc., Cary, NC) using proc GLM. Separation of means was done with the least significant difference method using alpha $=0.05$.

\section{Results and Discussion}

All 3 years were wetter than average years. The longterm annual average precipitation of $508 \mathrm{~mm}$ was exceeded before November 1 in all 3 years (Figures 1 \& 2). In all years, spring and early summer were wet, ensuring that the soil profile was approximately filled to field capacity with water at the beginning of each growing season. Atmospheric evaporative demand was the least in 2009 (Table 5).

In 2007, there was a rain event of over $40 \mathrm{~mm}$ in late July (Figure 1). The effect of this rain can be seen in the soil water content in all eight irrigation treatments: soil water content increased at several of the measured depths (Figure 4). The corn crop in the dryland treatment started depleting substantial amounts of soil water later in July down to a depth of approximately $1.07 \mathrm{~m}$ (Figure 4a). In August, the crop also used a significant amount of water from the 1.37 and $1.68 \mathrm{~m}$ depths. It is not clear from these data that all of the soil water depletion at these lower depths was direct water uptake by corn roots; some of it may have been soil water redistribution (water moving upwards toward drier soil).

In the second half of July in the dryland treatment, soil water content dropped below $0.20 \mathrm{~m}^{3} \mathrm{~m}^{-3}$ (below the MAD of $50 \%$ ) for the first time in the season, although at the deeper depths, it was still well above $0.20 \mathrm{~m}^{3} \mathrm{~m}^{-3}$ at this time (Figure 4a). The crop may have experienced some stress at this time, because soil water at these deeper depths is not as accessible to the crop. In the middle of August, soil water content was well below $0.20 \mathrm{~m}^{3} \mathrm{~m}^{-3}$ at all depths above $1.68 \mathrm{~m}$, suggesting that the dryland crop most likely experienced water stress at this time.

The corn crop in the 50\% ET treatment may have been stressed for water also during the second part of July since soil water content fell below $0.20 \mathrm{~m}^{3} \mathrm{~m}^{-3}$ for the top two measured depths and was exactly at $0.20 \mathrm{~m}^{3} \mathrm{~m}^{-3}$ for the $0.76 \mathrm{~m}$ depth (Figure $4 \mathrm{~b}$ ). Soil water content at the deeper depths was still above $0.20 \mathrm{~m}^{3} \mathrm{~m}^{-3}$, as it was for the dryland treatment, but that could probably not prevent the crop from experiencing water stress at this time. Crop water stress during this critical period of tasseling and silking (Table 2) is undesirable and can have a serious negative impact on crop yield. At the end of July, crop stress was relieved by the $40-\mathrm{mm}$ rain. After this, soil water content decreased again, and water stress was likely back in the $50 \%$ ET treatment by midAugust staying into September. 
Table 4. Water balance components for 2007-2009

\begin{tabular}{|c|c|c|c|c|c|c|c|c|c|}
\hline Trt. & $\begin{array}{l}\text { SWC1 } \\
(\mathrm{mm})\end{array}$ & $\begin{array}{l}\text { SWC2 } \\
(\mathrm{mm})\end{array}$ & $\begin{array}{l}\text { dSWC } \\
(\mathrm{mm})\end{array}$ & $\begin{array}{l}\text { Precip. } \\
(\mathrm{mm})\end{array}$ & $\begin{array}{l}\text { Irr. } \\
(\mathrm{mm})\end{array}$ & $\begin{array}{l}\mathrm{ET}_{\text {begin }} \\
(\mathrm{mm})\end{array}$ & $\begin{array}{l}\mathrm{ET}_{\text {end }} \\
(\mathrm{mm})\end{array}$ & $\begin{array}{l}\text { ET } \\
(\mathrm{mm})\end{array}$ & $\begin{array}{l}\text { WUE } \\
\left(\mathrm{kg} \mathrm{m}^{-3}\right)\end{array}$ \\
\hline 2007 & July 3 & Oct. 8 & & & & & & & \\
\hline DL & 439 & 297 & 142 & 152 & 41 & 107 & 0 & 442 & 2.02 \\
\hline 50 & 443 & 326 & 117 & 152 & 90 & 107 & 0 & 466 & 2.09 \\
\hline 75 & 439 & 330 & 109 & 152 & 177 & 107 & 0 & 545 & 2.00 \\
\hline 100 & 433 & 385 & 48 & 152 & 264 & 107 & 0 & 571 & 2.01 \\
\hline A1 & 468 & 370 & 98 & 152 & 158 & 107 & 0 & 515 & 2.11 \\
\hline A2 & 445 & 361 & 84 & 152 & 164 & 107 & 0 & 507 & 2.13 \\
\hline A3 & 454 & 344 & 110 & 152 & 196 & 107 & 0 & 565 & 1.97 \\
\hline $\mathrm{A} 4$ & 438 & 370 & 68 & 152 & 231 & 107 & 0 & 558 & 2.06 \\
\hline 2008 & June 11 & Oct. 16 & & & & & & & \\
\hline DL & 527 & 342 & 185 & 286 & 0 & 8 & 0 & 479 & 1.53 \\
\hline 50 & 556 & 366 & 190 & 286 & 74 & 8 & 0 & 557 & 1.65 \\
\hline 75 & 543 & 451 & 92 & 286 & 149 & 8 & 0 & 535 & 1.79 \\
\hline 100 & 530 & 487 & 44 & 286 & 221 & 8 & 0 & 558 & 1.73 \\
\hline A1 & 542 & 415 & 127 & 286 & 134 & 8 & 0 & 555 & 1.74 \\
\hline A2 & 517 & 409 & 109 & 286 & 147 & 8 & 0 & 550 & 1.79 \\
\hline $\mathrm{A} 3$ & 548 & 455 & 93 & 286 & 166 & 8 & 0 & 552 & 1.75 \\
\hline $\mathrm{A} 4$ & 543 & 445 & 98 & 286 & 194 & 8 & 0 & 586 & 1.62 \\
\hline 2009 & June 26 & Sept. 2 & & & & & & & \\
\hline DL & 520 & 294 & 225 & 179 & 17 & 60 & 66 & 548 & 2.39 \\
\hline 50 & 528 & 307 & 221 & 179 & 22 & 60 & 66 & 548 & 2.30 \\
\hline 75 & 506 & 346 & 161 & 179 & 93 & 60 & 66 & 559 & 2.30 \\
\hline 100 & 490 & 451 & 39 & 179 & 161 & 60 & 66 & 505 & 2.55 \\
\hline 125 & 542 & 528 & 15 & 179 & 220 & 60 & 66 & 540 & 2.43 \\
\hline A2 & 514 & 330 & 185 & 179 & 75 & 60 & 66 & 564 & 2.24 \\
\hline A3 & 531 & 393 & 139 & 179 & 120 & 60 & 66 & 564 & 2.40 \\
\hline A4 & 520 & 433 & 88 & 179 & 142 & 60 & 66 & 535 & 2.39 \\
\hline
\end{tabular}

Trt. $=$ irrigation treatment - definitions of irrigation treatments are given in Table 1; implementation of irrigation treatments is shown in Figure 3; SWC = soil water content in the top $1.83 \mathrm{~m}$; SWC1 = SWC on date indicated (first soil water measurement of the season); SWC2 = SWC on date indicated (last soil water measurement of the season); dSWC = SWC1 - SWC2; Precip. = precipitation between first and last soil water measurements of the season; Irr. = irrigation between first and last soil water measurements of the season; $\mathrm{ET}_{\text {begin }}=\mathrm{ET}$ from emergence to date of first soil water measurement of the season, from $\mathrm{HPRCC}$; $\mathrm{ET}_{\text {end }}=\mathrm{ET}_{\mathrm{F}}$ from last soil water measurement of the season to maturity, from HPRCC; HPRCC = High Plains Regional Climate Center; ET = estimated ET between emergence and maturity: ET $=\mathrm{dSWC}+$ Precip. + Irr. $+\mathrm{ET}_{\text {begin }}+\mathrm{ET}_{\text {end }}$; The ET calculation assumes that runoff and deep percolation of water below $1.83 \mathrm{~m}$ were insignificant; WUE = water use efficiency (grain yield/ET)

Soil water content for the $75 \%$ ET treatment (Figure 4c) was somewhat greater than that for the $50 \%$ ET treatment (Figure $4 \mathrm{~b}$ ). Thus, from the soil water data, it is expected that the crop on the $50 \%$ ET treatment would have been under greater water stress than the crop on the $75 \%$ ET treatment. Indeed, the crop yield on the $50 \%$ ET treatment was lower than that on the $75 \%$ ET treatment (Table 6). Soil water content in the $100 \%$ ET treatment stayed above $0.20 \mathrm{~m}^{3} \mathrm{~m}^{-3}$ for the entire season (Figure 4d); thus, it is not expected that the crop in this treatment experienced water stress at any time during the growing season. As expected, the $100 \%$ ET treatment yielded higher than the $0.75 \%$ ET treatment (Table 6).

All A treatments received full irrigation (the same as the $100 \%$ ET treatment) until August 10 (Figure 3a) when pollination was complete and silks were brown (Table 2). The A4 treatment received full irrigation until August 17. After this, in the last three weeks of the irrigation season, it received less than full irrigation, so that at the end of the season it had received $33 \mathrm{~mm}$ less than the $100 \%$ ET treatment (Figure 3a). This resulted in a soil water content being somewhat lower toward the end of 
Table 5. Corn crop evapotranspiration (ET) from High Plains Regional Climate Center station located less than $1 \mathrm{~km}$ from the study site

\begin{tabular}{llll}
\hline & 2007 & 2008 & 2009 \\
\hline Total season ET $(\mathrm{mm})$ & 617 & 582 & 556 \\
Maximum daily ET $(\mathrm{mm})$ & 10.9 & 10.7 & 9.1 \\
Number of days ET $\geq 10 \mathrm{~mm}$ & 6 & 3 & 0 \\
Number of days ET $\geq 9 \mathrm{~mm}$ & 10 & 12 & 3 \\
Number of days ET $\geq 8 \mathrm{~mm}$ & 28 & 24 & 12 \\
\hline
\end{tabular}

Total season $\mathrm{ET}=\mathrm{ET}$ between emergence and maturity

the season (Figure $4 \mathrm{~h}$ ) than in the full irrigation treatment (Figure 4d), but yields for both treatments were the same at $11.5 \mathrm{Mg} \mathrm{ha}^{-1}$ (Table 6). Thus, this lower soil water content apparently did not impose water stress on the crop.

The A3 treatment received full irrigation until August 15. After this, it received less than full irrigation so that at the end of the season it had received $68 \mathrm{~mm}$ less than the $100 \%$ ET treatment (Figure 3a). This resulted in a soil water content being lower toward the end of the season (Figure 4g) than in the full irrigation treatment (Figure $4 \mathrm{~d}$ ) and also somewhat lower compared to the A4 treatment (Figure $4 \mathrm{~h}$ ), which may have resulted in some water stress, but yield for the A3 treatment was only a little less (11.2 vs. $11.5 \mathrm{Mg} \mathrm{ha}^{-1}$, difference not statistically significant, Table 6). Soil water content fell below $0.20 \mathrm{~m}^{3} \mathrm{~m}^{-3}$ in the second part of August and in September for the A1 (Figure 4e) and A2 (Figure 4f) treatments, but yields for these treatments were not much less than those for the A4 and 100\% ET treatments (Table 6), suggesting that some drying out of the soil below $0.20 \mathrm{~m}^{3} \mathrm{~m}^{-3}$ toward the end of the growing season has a minimal impact on corn yield.

In 2007, there was a clear response to irrigation water when going from DL to full irrigation: yield increased from $8.9 \mathrm{Mg} \mathrm{ha}^{-1}$ with a seasonal irrigation total of $41 \mathrm{~mm}$ to $11.5 \mathrm{Mg} \mathrm{ha}^{-1}$ with an irrigation total of $264 \mathrm{~mm}$ (Table 6). The DL treatment was not truly dryland (rainfed) in 2007, because at the beginning of the irrigation season it received some irrigation water with fertigation through the SDI system. There was only a slight yield increase in the A treatments going from $10.9 \mathrm{Mg} \mathrm{ha}^{-1}$ with $158 \mathrm{~mm}$ of irrigation water for the season for A1 to $11.5 \mathrm{Mg} \mathrm{ha}^{-1}$ with $231 \mathrm{~mm}$ of irrigation water for A4.

In 2008, as in 2007, the soil profile was approximately filled to field capacity with water at the beginning of the growing season (Figure 5). Soil water content in the dryland treatment was also close to field capacity at the beginning of the season (Figure 5a), even though the same dryland plots were well depleted of soil water at the end of the 2007 growing season (Figure 4a).

In 2008, corn in the dryland treatment started de- pleting substantial amounts of soil water in July down to a depth of about $1.07 \mathrm{~m}$ (Figure 5a). In August, the crop also used a significant amount of water from the 1.37 and $1.68 \mathrm{~m}$ depths. In the middle of July, soil water content dropped below $0.20 \mathrm{~m}^{3} \mathrm{~m}^{-3}$ for the first time in the season, but only at the $0.46 \mathrm{~m}$ depth. At the other depths, it was still well above $0.20 \mathrm{~m}^{3} \mathrm{~m}^{-3}$ at this time, so it is unlikely that the crop experienced water stress. At the beginning of August, soil water content was well below $0.20 \mathrm{~m}^{3} \mathrm{~m}^{-3}$ at the $0.46,0.76$, and $1.07 \mathrm{~m}$ depths, suggesting that the crop most likely experienced water stress at this time. Soil water content in the $100 \%$ ET treatment stayed above $0.20 \mathrm{~m}^{3} \mathrm{~m}^{-3}$ for most of the season as it should to avoid water stress on the crop (Figure $5 b$ ). Only in late July, did it drop slightly below this level, but only at the $0.46 \mathrm{~m}$ depth, so it is not expected that the crop experienced water stress at any time during the growing season.

In 2008, amount or timing of irrigation did not have much of an effect on yields, except for the dryland treatment where yield was substantially less than that for the other treatments (Table 6). Yields were suppressed across the irrigation treatments. These low yields were not unique to our experiment; the majority of the fields at WCREC had low yields, similar to the ones in this study. There was probably not one single cause, but a number of factors may have played a role. A hail storm in July damaged many leaves. Also, planting was later than average because of the wet and cool spring weather. The corn only emerged in the beginning of June (Table 2).

It is unlikely that the low 2008 yields were caused by water stress: more irrigation water on the $100 \%$ ET treatment did not increase yield compared to the yields on the 75, A1, A2, and A3 treatments (Table 6). Also, soil water content does not suggest crop water stress on the $100 \%$ ET treatment (Figure 6b). Only toward the end of July, soil water content dropped slightly below $0.20 \mathrm{~m}^{3} \mathrm{~m}^{-3}$ and only for one of the six measured depths.

In 2009, the near-surface soil was wetter (Figure 6) than that in 2007 (Figure 4) and 2008 (Figure 5) for much of the growing season, because there was more in-season (June, July, and August) precipitation (Figs. 1, 2). Soil in the DL (Figure 6a) and 50\% ET (Figure 6b) treatments did not get as dry as in 2007 and 2008. Steadily increasing soil water readings in August suggest that the $125 \%$ ET treatment was overwatered (Figure 6c). Because there was more in-season precipitation in 2009, less irrigation water was applied compared to 2007 and 2008 (Figure 3c). Because of this higher in-season precipitation, the 50 and $75 \%$ ET treatments especially required little irrigation in 2009. Precipitation provided most of the $50 \%$ ET requirement so that only a season total of $30 \mathrm{~mm}$ of irrigation water was applied in this treatment. Similarly, only a little over $100 \mathrm{~mm}$ water 

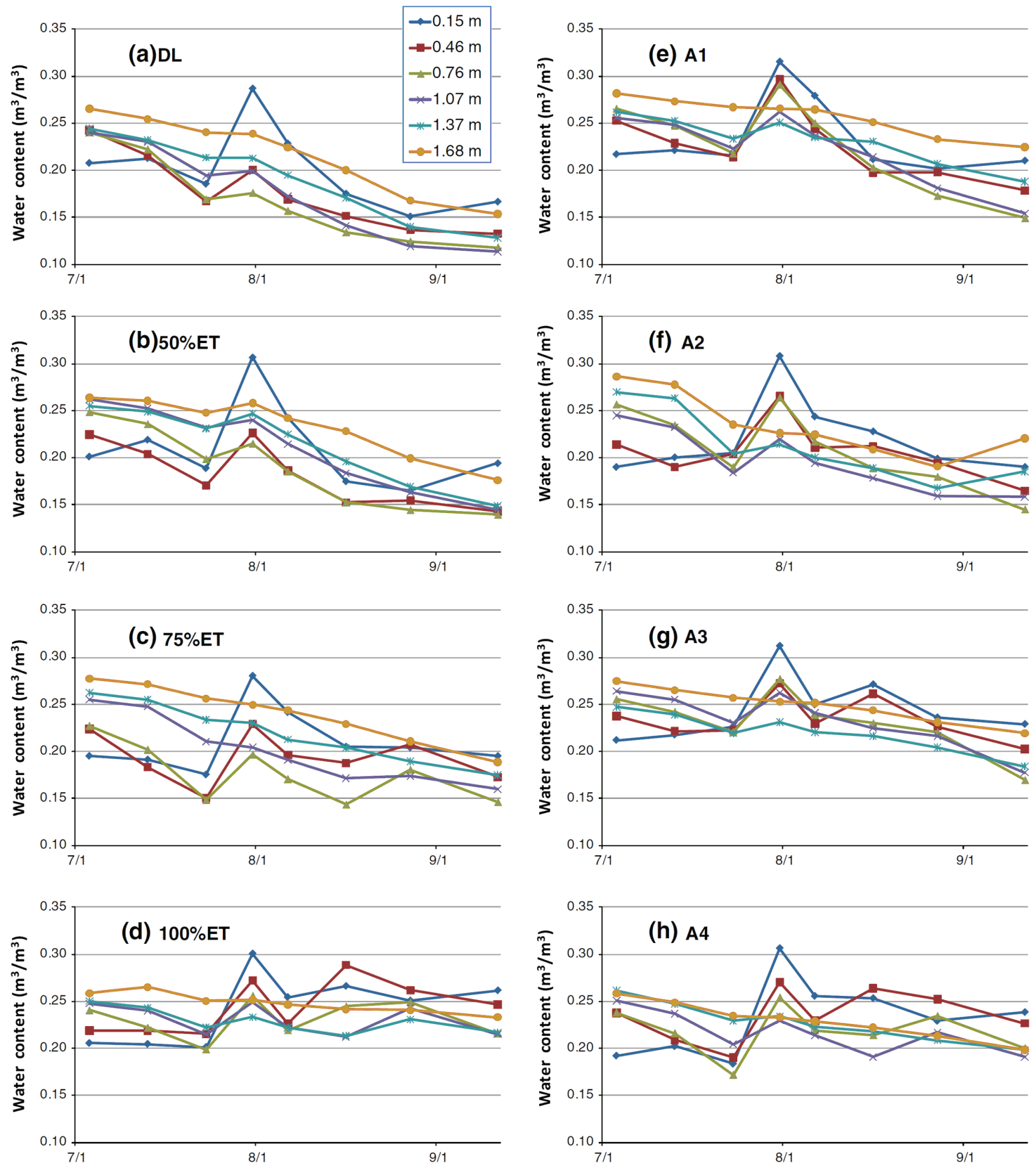

Figure 4. Soil water content $\left(\mathrm{m}^{3} \mathrm{~m}^{-3}\right)$ in 2007 at six different soil depths for eight irrigation treatments. Descriptions of irrigation treatments are given in Table 1.

was applied in the $75 \%$ ET treatment (Figure 3c). The cooler weather in 2009, with a lower atmospheric evaporative demand for ET (Table 5), also contributed to the lower irrigation requirements.

Much of the irrigation water was applied after midAugust (Figure 3c), after the most water-stress sensitive stages of tasseling, silking, and pollination. After midAugust, the soil in the DL and 50\% ET treatments dried out considerably (Figure 6a, b), but this did not lead to yield losses (Table 6). Apparently, in this later stage, the corn crop was able to tolerate greater soil water deple- tion without suffering any yield loss. This was also observed in 2007 with some of the A treatments as discussed earlier. They received less than full irrigation in the last few weeks of the irrigation season without suffering much yield loss.

In addition, the lower atmospheric demand in 2009 (Table 5) may have been another reason why low soil water contents, for example in the DL and 50\% ET treatments, did not cause crop water stress with subsequent yield loss. This effect has been documented by several researchers (Denmead and Shaw 1962; Allen et al. 1998; 

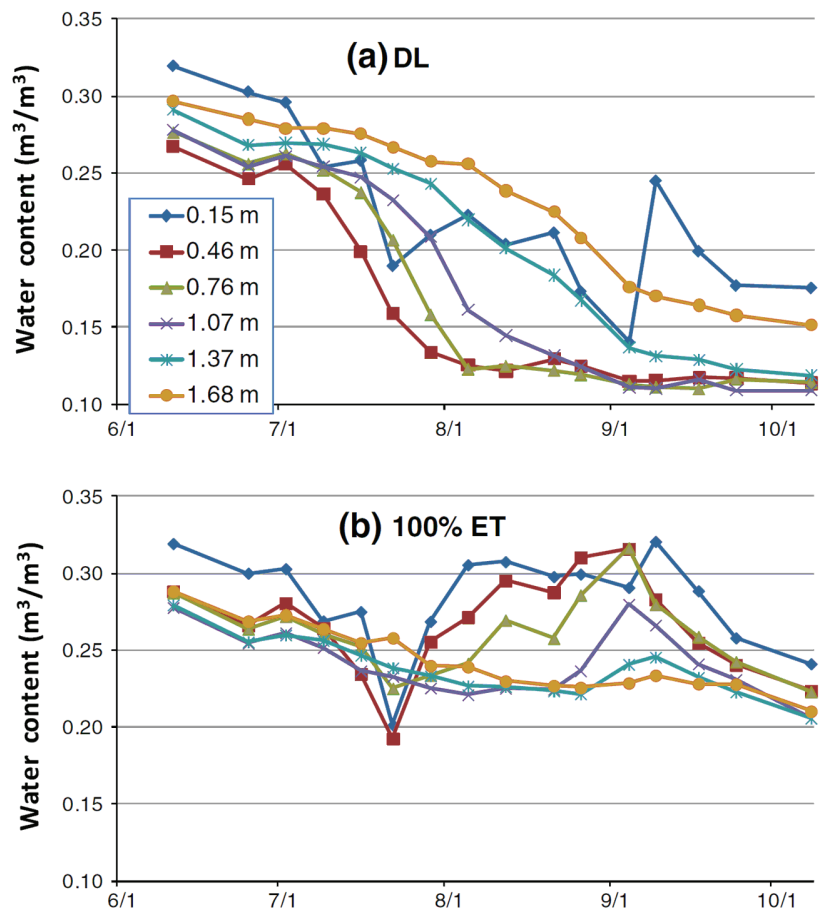

Figure 5. Soil water content $\left(\mathrm{m}^{3} \mathrm{~m}^{-3}\right)$ in 2008 at six different soil depths for two selected irrigation treatments. Descriptions of irrigation treatments are given in Table 1.

Table 6. Mean yields $\left(\mathrm{Mg} \mathrm{ha}^{-1}\right)$ for 2007-2009

\begin{tabular}{llll}
\hline Trt. & 2007 & 2008 & 2009 \\
\hline DL & $8.9 \mathrm{a}$ & $7.3 \mathrm{a}$ & $13.1 \mathrm{a}$ \\
50 & $9.7 \mathrm{~b}$ & $9.2 \mathrm{~b}$ & $12.6 \mathrm{a}$ \\
75 & $10.9 \mathrm{c}$ & $9.6 \mathrm{~b}$ & $12.9 \mathrm{a}$ \\
100 & $11.5 \mathrm{~d}$ & $9.7 \mathrm{~b}$ & $12.9 \mathrm{a}$ \\
125 & - & - & $13.1 \mathrm{a}$ \\
$\mathrm{A} 1$ & $10.9 \mathrm{c}$ & $9.7 \mathrm{~b}$ & - \\
$\mathrm{A} 2$ & $10.8 \mathrm{c}$ & $9.8 \mathrm{~b}$ & $12.7 \mathrm{a}$ \\
A3 & $11.2 \mathrm{~cd}$ & $9.7 \mathrm{~b}$ & $13.5 \mathrm{a}$ \\
A4 & $11.5 \mathrm{~d}$ & $9.5 \mathrm{~b}$ & $12.8 \mathrm{a}$ \\
\hline
\end{tabular}

Trt. = irrigation treatment - definitions of irrigation treatments are given in Table 1; implementation of irrigation treatments is shown in Figure 3. Within each year, the same letters behind yield values indicate no statistically significant difference at the 0.05 level

Orfanus and Eitzinger 2010). They showed that crop water stress does not simply occur once soil water content drops below a certain level, for example a MAD of $50 \%$, but that this level depends on atmospheric demand, with the level being lower at a lower atmospheric demand.

The range in ET between the irrigation treatments was small in 2009, from 505 to $564 \mathrm{~mm}$ (Table 4). Seasonal ET for the DL and 50\% ET treatments was not less than that of the other treatments (Table 4), indicating that, even in
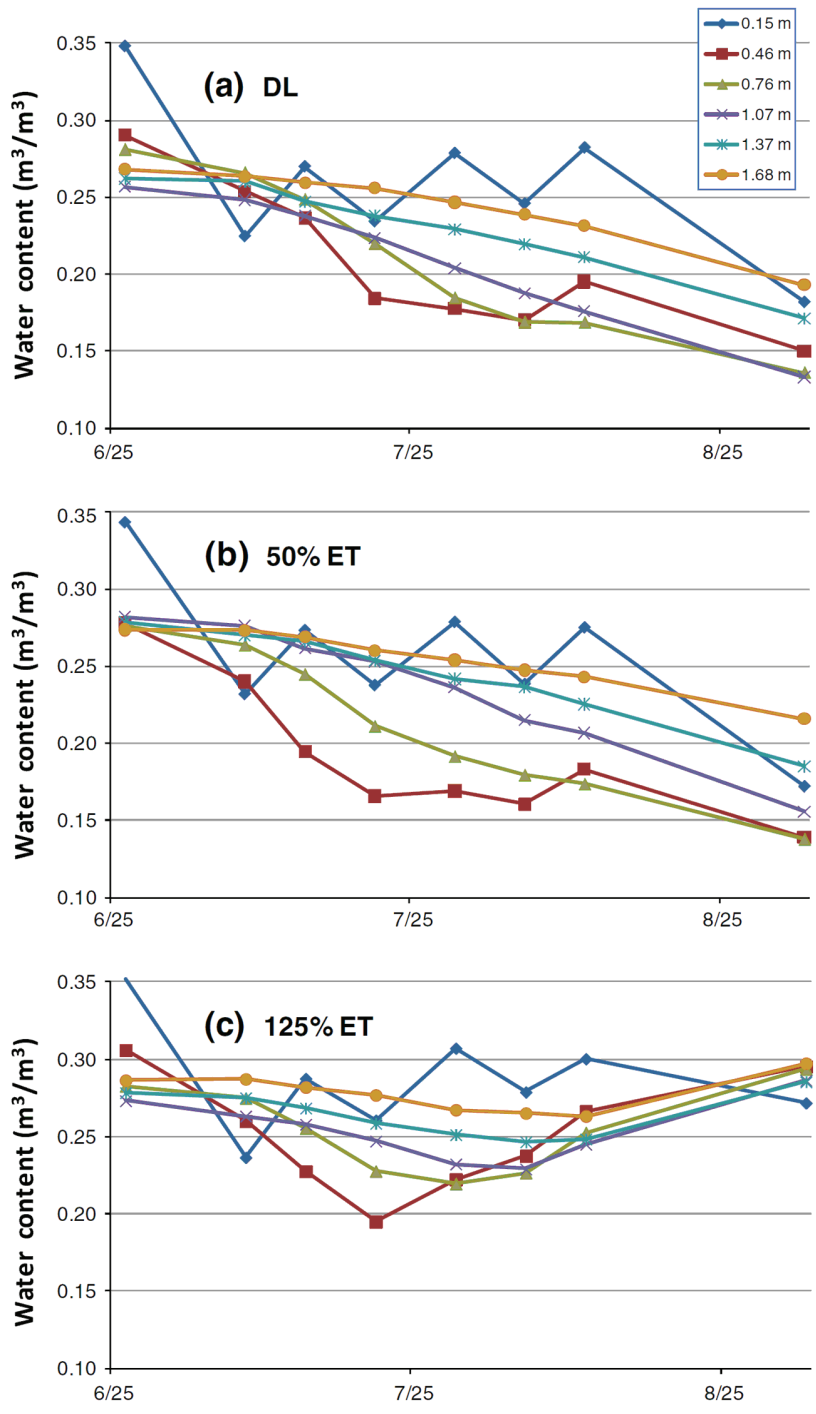

Figure 6. Soil water content $\left(\mathrm{m}^{3} \mathrm{~m}^{-3}\right)$ in 2009 at six different soil depths for three selected irrigation treatments. Descriptions of irrigation treatments are given in Table 1.

the low-irrigation treatments, corn roots did not have significant difficulty extracting the soil water necessary for growing a crop relatively free of water stress.

Seasonal ET was rather low, staying below $600 \mathrm{~mm}$ in all 3 years for all irrigation treatments (Table 4). This indicates that the assumption, for the ET calculation, of no runoff or deep percolation was probably not violated, which is consistent with our observations in the field plots. Furthermore, limited evaporation may have reduced ET. Evaporation was likely limited because of the soil surface staying dry when irrigating with SDI systems and because of the no-till practices that were used with plenty of corn residues (nearly $100 \%$ cover) covering the soil surface (Nielsen et al. 2005; Klocke et al. 2009; van Donk et al. 2010; Grassini et al. 2011). 
Water use efficiency (WUE), defined as grain yield divided by ET, did not vary much between the irrigation treatments within a given year (Table 4). In 2007, the A2 treatment had the maximum WUE at $2.13 \mathrm{~kg} \mathrm{~m}^{-3}$, and the $\mathrm{A} 3$ treatment had the minimum at $1.97 \mathrm{~kg} \mathrm{~m}^{-3}$. In 2009 , the $100 \%$ ET treatment had the maximum WUE at $2.55 \mathrm{~kg} \mathrm{~m}^{-3}$, and the $\mathrm{A} 2$ treatment had the minimum at $2.24 \mathrm{~kg} \mathrm{~m}^{-3}$.

\section{Conclusions}

In each of the 3 years, less than $40 \mathrm{~mm}$ of irrigation water was applied before tasseling in the fully irrigated treatment, so the effect of water stress before tasseling on corn yield could not be properly evaluated in this experiment. In 2007, there was a clear response of corn yield to total season irrigation amount, from a mean yield of $8.9 \mathrm{Mg} \mathrm{ha}^{-1}$ for the least irrigated treatment (season total of $41 \mathrm{~mm}$ of irrigation water) to $11.5 \mathrm{Mg} \mathrm{ha}^{-1}$ for the fully irrigated treatment (100\% ET, $264 \mathrm{~mm}$ of irrigation water).

There was only a $5 \%$ yield decrease for the treatment with the greatest reduction in irrigation water after tasseling and silking (A1 treatment: $10.9 \mathrm{Mg} \mathrm{ha}^{-1}$ with $158 \mathrm{~mm}$ of seasonal irrigation water) compared to the fully irrigated treatment. For the A1 treatment, soil water content fell below $0.20 \mathrm{~m}^{3} \mathrm{~m}^{-3}$ (below a MAD of $50 \%$ ) in the second part of August and in September. This drier soil toward the end of the growing season only reduced yield by $5 \%$ compared to the fully irrigated treatment while saving more than $100 \mathrm{~mm}$ of irrigation water.

In 2008, yields were suppressed across the irrigation treatments. Amount or timing of irrigation did not have a statistically significant effect on yields, except for the dryland treatment where yield was $24 \%$ less than for the other treatments. Reasons for the low yields included a hailstorm in July and late planting and emergence caused by wet and cool weather and soil.

In 2009, there were no significant differences in yield between the irrigation treatments. There may have been several reasons for this outcome. First, there was more in-season precipitation in 2009 than in 2007 and 2008, requiring less irrigation water. Second, the cooler weather in 2009, with a lower atmospheric evaporative demand, also contributed to the lower irrigation requirements. Third, much of the irrigation water was applied after mid-August, after the most water-stress sensitive stages of tasseling, silking, and pollination; after mid-August, the soil in the low-irrigation treatments dried out considerably without causing yield losses. Finally, the lower atmospheric demand in 2009 may have been another reason why soil water contents well below a MAD of $50 \%$, for example in the dryland and $50 \%$ ET treatments, did not cause any yield losses.
Seasonal ET stayed below $600 \mathrm{~mm}$ in all three years for all irrigation treatments. Limited evaporation may have kept ET this low. Evaporation was likely limited because of the soil surface staying dry when irrigating with an SDI system and because of the no-till practices that were used with a nearly $100 \%$ cover of corn residue covering the soil surface all the time.

Acknowledgments - The authors would like to acknowledge the assistance provided by Eugene Richter during the field study.

\section{References}

Allen RG, Pereira LS, Raes D, Smith M (1998) Crop evapotranspiration - guidelines for computing crop water requirements. Irrigation and drainage paper 56. Food and Agriculture Organization of the United Nations (FAO), Rome

Camp CR (1998) Subsurface drip irrigation: a review. Trans ASAE 41(5):1353-1367

Colaizzi PD, Schneider AD, Evett SR, Howell TA (2004) Comparison of SDI, LEPA, and spray irrigation performance for grain sorghum. Trans ASAE 47(5):1477-1492

Denmead OT, Shaw RH (1962) Availability of soil water to plants as affected by soil moisture content and meteorological conditions. Agron J 54:385-390

Evett SR, Steiner JL (1995) Precision of neutron scattering and capacitance type soil water content gauges from field calibration. Soil Sci Soc Am J 59:961-968

Grassini P, Yang H, Irmak S, Thorburn J, Burr C, Cassman KG (2011) High-yield irrigated maize in the Western U.S. Corn Belt: II. Irrigation management and crop water productivity. Field Crop Res 120:133-141

Howell TA, Schneider AD, Evett SR (1997) Subsurface and surface microirrigation of corn-Southern High Plains. Trans ASAE 40(3):635-641

Klocke NL, Watts DG, Schneekloth JP, Davison DR, Todd RW, Parkhurst AM (1999) Nitrate leaching in irrigated corn and soybean in a semi-arid climate. Trans ASAE 42(6):16211630

Klocke NL, Currie RS, Aiken RM (2009) Soil water evaporation and crop residues. Trans ASABE 52(1):103-110

Lamm FR, Camp CR (2007) Subsurface drip irrigation. In: Lamm FR, Ayars JE, Nakayama FS (eds.) Microirrigation for crop production - design, operation and management. Elsevier, Amsterdam, pp 473-551

Lamm FR, Trooien TP (2001) Irrigation capacity and plant population effects on corn production using SDI. In: Proceedings of the irrigation association international irrigation technical conference, Nov 4-6, 2001, San Antonio, TX. Available from Irrigation Association, Falls Church VA, pp 73 80

Lamm FR, Manges HL, Stone LR, Khan AH, Rogers DH (1995) Water requirement of subsurface drip-irrigated corn in northwest Kansas. Trans ASAE 38(2):441-448 
Lamm FR, Rogers DH, Alam M, O’Brien DM, Trooien TP (2011) Twenty-two years of SDI research in Kansas. In: Proceedings of the 23rd annual central plains irrigation conference, Burlington, Colorado, Feb 23-24, 2011. Available from CPIA, 760 N. Thompson, Colby, KS, pp 68-92

McGuire VL (2004) Water level changes in the high plains aquifer, predevelopment to 2002, 1980-2002, and 2001-2002. Fact Sheet 2004-3026. U.S. Geological Survey, Lincoln, NE

McGuire VL, Fischer BC (1999) Water level changes, 1980-1997 and saturated thickness, 1996-1997, in the High Plains Aquifer. Fact Sheet 124-99. U.S. Geological Survey, Lincoln, Nebraska

Nielsen DC, Unger PW, Miller PR (2005) Efficient water use in dryland cropping systems in the Great Plains. Agron J 97:364-372

Orfanus T, Eitzinger J (2010) Factors influencing the occurrence of water stress at field scale. Ecohydrology 3:478-486

Payero JO, Melvin SR, Irmak S (2005) Response of soybean to deficit irrigation in the semi-arid environment of west-central Nebraska. Trans ASABE 48(6):2189-2203

Payero JO, Klocke NL, Schneekloth JP, Davison DR (2006a) Comparison of irrigation strategies for surface-irrigated corn in West Central Nebraska. Irrig Sci 24(4):257-265

Payero JO, Melvin SR, Irmak S, Tarkalson D (2006b) Yield response of corn to deficit irrigation in a semiarid climate. Agric Water Manag 84:101-112

Payero JO, Tarkalson DD, Irmak S, Davison DR, Petersen JL (2008) Effect of irrigation amounts applied with subsurface drip irrigation on corn evapotranspiration, yield, water use efficiency, and dry matter production in a semiarid climate. Agric Water Manag 95:895-908
Payero JO, Tarkalson DD, Irmak S, Davison DR, Petersen JL (2009) Effect of timing of a deficit-irrigation allocation on corn evapotranspiration, yield, water use efficiency and dry mass. Agric Water Manag 96:1387-1397

Schneekloth JP, Klocke NL, Davison DR, Payero JO (2006) Furrow irrigation management with limited water. Appl Eng Agric 22:391-398

Steiner JL (1989) Tillage and residue effects on evaporation from soils. Soil Sci Soc Am J 53:911-916

Todd RW, Klocke NL, Hergert GW, Parkhurst AM (1991) Evaporation from soil influenced by crop shading, crop residue, and wetting regime. Trans ASAE 34:461-466

USDA (1978) Soil survey of Lincoln County, Nebraska. A publication of the U.S. Department of Agriculture Soil Conservation Service, in cooperation with University of Nebraska Conservation and Survey Division

van Donk SJ, Tollner EW, Steiner JL, Evett SR (2004) Soil temperature under a dormant bermudagrass mulch: Simulation and measurement. Trans ASAE 47:91-98

van Donk SJ, Martin DL, Irmak S, Melvin SR, Petersen JL, Davison DR (2010) Crop residue cover effects on evaporation, soil water content, and yield of deficit-irrigated corn in west-central Nebraska. Trans ASABE 53(6):1787-1797 